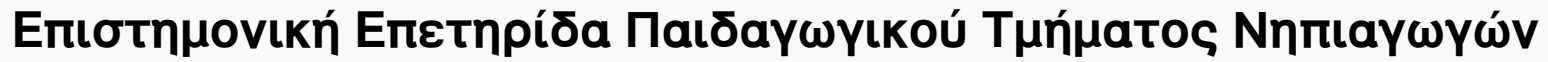 חavertotnuíou Iwavvívwv
}

Tóp. 8 (2015)

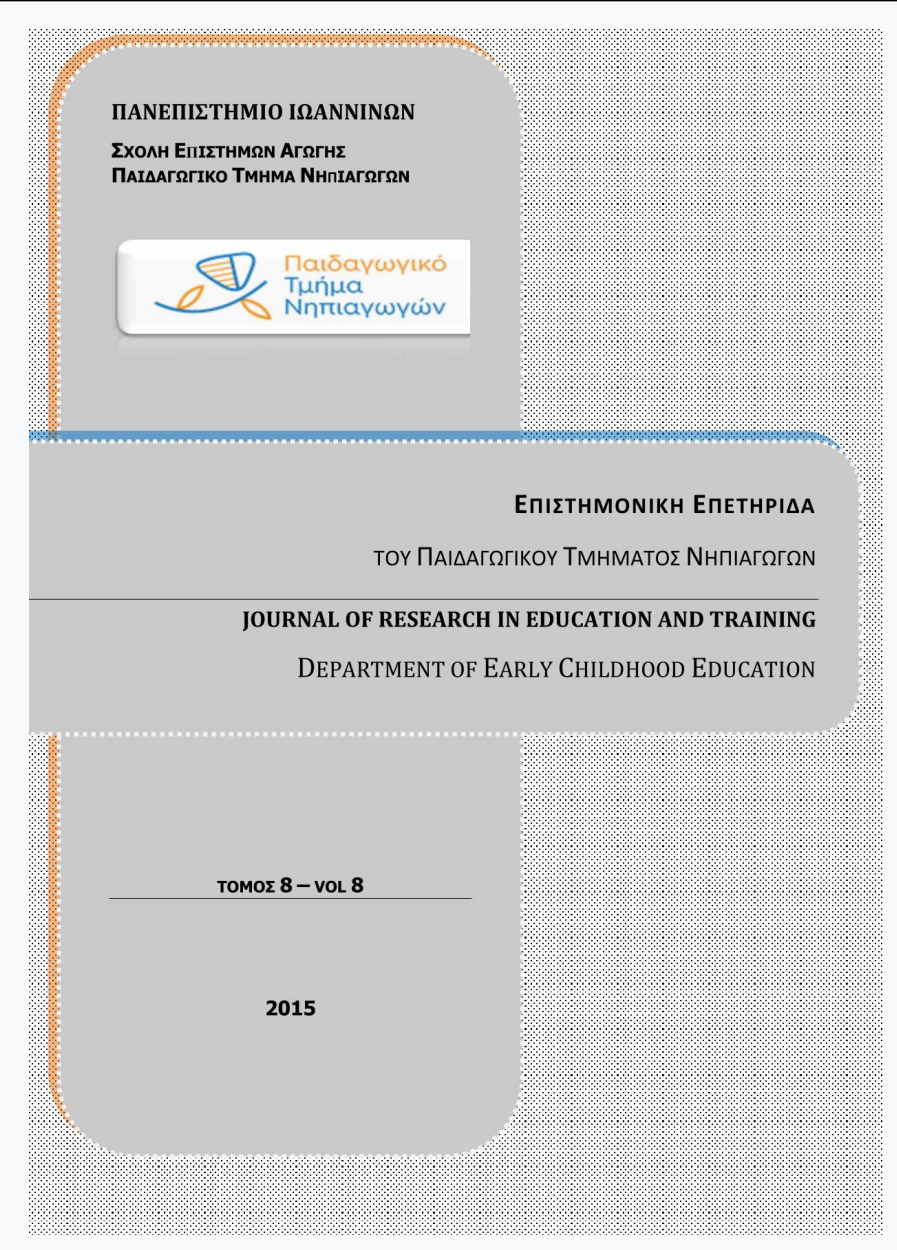

The main aspects of the application of educational technologies in the study process

Leta Dromantienè, Valdonè Indrašiené, Jenny Pange, Erika Bielskytè - Simanavičienè

doi: $10.12681 /$ jret.9081

Copyright (C 2016, Leta Dromantienè, Valdonè Indrašienè, Jenny Pange, Erika Bielskytè - Simanavičienè

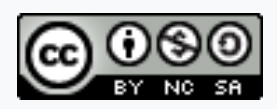

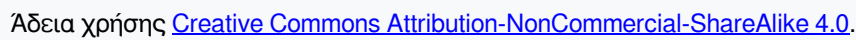

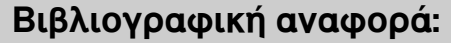

Dromantienè, L., Indrašienè, V., Pange, J., \& Bielskytè - Simanavičienè, E. (2015). The main aspects of the application of

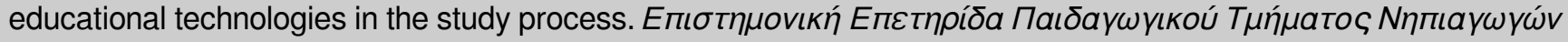

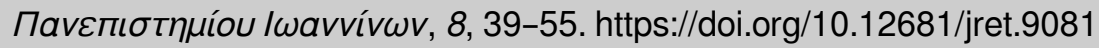




\begin{tabular}{r|l} 
Journal of Research in Education and Training & Volume \\
Department of Early Childhood Education, University of Ioannina & 8 (2015)
\end{tabular}

\title{
The main aspects of the application of educational technologies in the study process
}

\author{
Leta Dromantiené $\dot{1}^{1}$, Valdonė Indrašiené ${ }^{1}$, Jenny Pange ${ }^{2}$, Erika Bielskytè - \\ Simanavičienè ${ }^{1}$ \\ ${ }^{1}$ Faculty of Social Technologies, Mykolas Romeris University \\ ${ }^{2}$ School of Education, University of Ioannina
}

\begin{abstract}
Rapidly changing economic, social and political conditions, the penetration of new technologies also requires a completely different type of the university lecturers who are innovation-friendly. They must have relevant knowledge and combine didactic technologies and information and communication technologies in order that they would be able to give students an opportunity to study in an innovative and effective way. Taking into consideration that the study process is always based on a certain technology and paying attention to the shift of education paradigms, it can be established that, in the modern study process, it is extremely important to realise precisely today's educational objectives and principles which assist in implementing up-to-date educational technologies. The study is aimed at establishing what most important factors of the application of educational technologies in the process of modern studies are. The study is based on a quantitative research methodology the choice of which was determined by the newness of the analyzed problem. The study shows that the objectives of a subject of studies are always discussed with students, the latter also have an opportunity to set their own individual study objectives, they are continuously kept informed why they study concrete knowledge and what it will be needed for in the future. The creation of an environment favourable to studies is also proved by the fact that the opportunity is given to students to combine the content of their studies of a subject with their own personal experience, interests. The study process is dominated by the study process of the active creation and construction of knowledge.
\end{abstract}

Key words: a higher education institution, an innovative activity, an educational technology.

Correspondent Author: Leta Dromantienè

Department: Faculty of Social Technologies, University: Mykolas Romeris

University

e-mail: dromante@mruni.eu

e-publisher: National Documentation Centre, National Hellenic Research

Foundation URL: http://ejournals.epublishing.ekt.gr/index.php/jret/index 


\section{Introduction}

The development of information and communication poses new challenges to education and processes related to the latter. As the digital culture is sculpturing a new reality to which school's practices need to be adapted, this fact calls for a transformation in schools. (Hayashi \& Baranauskas, 2013). Therefore, the structure of a modern higher education institution is inconceivable without equipping a learner with effective learning instruments, tools corresponding to his learning style and needs (Longworth, 2000), an interactive system of studies which is the totality of technologies of integrated interactive information and communication and didactic tools and their application. Conceiving educational technologies as the system of educational actions, it can be presumed that today the empowerment of the study process is inconceivable without educator's abilities to properly manage these technologies. Changes in the education system and society impose new requirements to the educators (Dromantienè, et al., 2013).

In context of a new educational paradigm, particular emphasis is given to the integration of information and communication technologies (further - ICT) to ensure efficient and effective teaching/learning (Spector\&Merrill, 2008). It should be noted that, although the use of ICT in education has increased (Greenhow et al., 2009), it was established that quite a few problems, which are related to the application ICT in the study process, are still encountered. Educators feel insufficiently prepared to use technologies and implement new teaching strategies (Brown \& Warschauer, 2006), they do not use their creative potential to the fullest (Fredriksson et al., 2009) and most often apply technologies only to transmit information (Gao et al., 2009).

In order to realise educational technologies in the study process, particular significance is attached to the application of active, innovative teaching and learning methods, the establishment of conditions to choose them (Stoll \&Fink, 1998, Anderson, 2005). Thus the expression of educational technologies is directly linked to information technologies the intensive dissemination of which inevitably changes the whole educational process. The penetration of the latter technologies into the study process obliges teachers to organise teaching and learning while using innovative tools, it establishes the conditions for the creation of a modern educational environment.

According to scientists in European higher education institutions, while students and teachers seem to be using the new available technologies more and more intensively, organisational designs are changing slowly“ (Youssef \& Mounirn, p.53) The research indicates that ,even in schools with experiences of pedagogical improvements and technology, teachers face diverse problems when integrating new pedagogical practices and new technology (Ilomäki, 2008). Thus the changing concept of teaching/learning, educational environment, the accelerating development of information technologies determines Problematic issues: to establish what 
preconditions for the creation of the educational environment favourable to teaching/learning are, what the most important aspects of the application of teaching and learning methods and what opportunities of the integration of information and communication technologies in the study process are.

The objective is to examine didactic factors of the application of educational technologies in the study process.

The subject of the study: the application of educational technologies in the study process.

The methodology of the study. The study is based on a qualitative research methodology the choice of which was determined by the newness of the analysed problem. Six teachers of the Y faculty of X university, who participated in the study, were selected by applying random target selection. A data selection method of the study - a semi-structured interview.

Study limitations. In order to theoretically and empirically substantiate the opportunities of the application of educational technologies in the study process, the 1 teachers of one faculty of one university were interviewed, therefore, the conclusions are not applicable to the whole population of 1 teachers.

\section{Educational Technologies in the processes of change}

The transformation of educational paradigm, which has occurred due to the rapid change of societal life, continuous changes of the structure of social and economic system, political decisions made regarding education determine a new approach towards teaching, whereas all that determines the emergence of up-to-date educational technologies and the preconditions for their application when realising educational processes. The Association for Educational Communications and Technology defines educational technologies as "the study and ethical practice of facilitating learning and improving performance by creating, using, and managing appropriate technological processes and resources" (AECT Standards, 2012) ${ }^{1}$ In scientific literature (Ross et al., 2010), educational technologies are defined as the system of actions which manifests itself though an arrangement of innovative teaching forms, methods, the regulation of teaching content, the design, organisation and implementation of the teaching process, using and combining technical and human resources. According to other researchers (Luppicini, 2005), definition of Educational Technology as goal oriented problemsolving systems approach utilizing tools, techniques, theories, and methods from multiple knowledge domains, to: design, develop, and evaluate, human and mechanical resources efficiently and effectively in order to facilitate and leverage all aspects of learning, and guide change agency and transformation of educational systems and practices in order to contribute to influencing change in society. Thus Educational Technology: is the field concerned with the design, development, utilization, management, and evaluation of processes and resources for learning.

\footnotetext{
${ }^{1}$ http://c.ymcdn.com/sites/aect.site-

ym.com/resource/resmgr/AECT_Documents/AECT_Standards_adopted7_16_2.pdf
} 
Despite the fact that, in the new educational paradigm, priorities are given to the learning process which is oriented exactly towards a student, who actively expands and develops his uderstanding, knowledge, competences, values, however, in such a way, essential changes are emphasised not only in the activity of a learner, but also in that of a teacher. The role of the teacher in modern study process is more and more often understood as the role of the assistant who takes care of the knowledge creation process of the learner. This in fixes the student-needs-orientated learning paradigm in the university preparation (Indrašienė \& Sadauskas, 2013).

When talking about educational paradigm shifts and the empowerment of up-to-date educational technologies related to this process in the study process, an emphasis must be given to the change of the main interaction elements of the didactic process: study objectives, teaching and learning methods, the study content. According to the researchers (Šiaučiukienè \& Čiužas, 2006), when learners set themselves their study objectives they have an opportunity to verify that the objectives are achieved through greater or lesser efforts.

Another important didactic element, determining the application of educational technologies, is teaching and learning methods. When talking about teaching and learning methods the emphasis must be given that modern teaching/learning tendencies reflect the transition from conventional, commonly agreed teaching methods to unconventional innovative teaching methods which promote interactive learning forms, an active participation of a learner, integral thinking, when the roles and relationships between an educator and his educatee radically change. Therefore, in the study process, methods, by applying which information technologies are used, are important, because the use of ICT has a positive influence on the development of the competences of different subjects (Youssef \& Mounir, 2008). It was established that The main factor determining the level of students' ICT skills is the educator capable of organising and managing the ICT-based teaching/learning process in a creative manner. The educators mastering ICT skills realise that ICT usage for educational reasons has a positive impact on education and can increase the effectiveness of the process; this determines diversity of ICT usage goals (Indrašienè et al., 2015).

Finally, it is appropriate to define the study content planning and implementation in the change of educational technologies. Curriculum is a complex endeavor suffering in a permanent discussion both about its theoretial state and the relationship between curriculum theory and curriculum development. Curriculum development is a dynamic process, it changes according to the need of the society and the stakeholders of the education system. The curriculum development process includes several stages such as planning, preparing, designing, developing, implementing, evaluating, revising, and improving (Patankar \& Jadhav, 2013) 
According to the researchers (Barnet\&Coate, 2005), a subject curriculum of studies should to be open, left for a free learner's choice. A curriculum, in the academic community, is meaningful not only due to the fact that fundamental knowledge is acquired, created and disseminated, but in particular due to the fact that it opens up prospects for students to perfect their personality, to develop the needs of free and responsible self-expression, consolidate competences, qualifications and skills necessary for that (Indrašienè \& Sadauskas, 2013). That means it could be established that a curriculum becomes more corresponding to the learner's needs and his interests: it provides an opportunity to study for all and prepares every student for a real life. Consequently, the study content is closely linked to the learner's interests and needs, his aspirations, whereas professional knowledge is inseparable from the experiences of a daily personal life.

Pursuant to the concept of modern educational paradigm, studies are deemed to be a constructive activity of a learner himself, empowering a learner to get actively engaged in the learning activity, to set himself study objectives. The empowerment of all this educational interaction and its main elements requires an efficient application of educational technologies in the study process and an environment favourable to studies.

\section{The role of the teacher in the context of innovative activity}

The role of teachers as knowledge society builders is related to their scientific activity whilst understanding that higher education institutions should not only pursue fundamental or applied research but also develop new methodologies, foster innovation and educate society (Rastauskienè et al., 2008). In view of this, teachers' work is defined through major activities and is related to the production, transmission and dissemination of knowledge (Havelock \& Hamilton, 2004); this teachers' activity is limited to the three main composite parts: pedagogical, scientific and dissemination activity.

The changing higher education environment and educational paradigm, as well as ICT developments determine the emergence of a modern education content, new methods and strategies and innovative attitudes. It is agreed that efficient use of these teaching/learning components depends on the teacher's activity. Therefore, in order to create a modern and interactive study system meeting the needs of a contemporary society, it is necessary to increase the level of the teachers' ICT competence and prepare teachers for innovation-driven growth. Usually innovation-driven and competent teachers give preference to the educational paradigm reflecting a democratic teaching style, the ability to use ICT as interactive learning, the use of various teaching/learning methods and tools contributing to the development of favourable educational environment. Electronic learning environments are rational systems which take a lot of work off teachers' shoulders. Teachers must know what programmes are available that are suitable for their students' individual needs and 
keep abreast of this. They need to be the arrangers or planners of students' learning processes: they bring together the educational tools and set them up in a particular way. (Zhu, 2010). ICT, the usage of smart educational products help teachers bring more collaboration and interactivity into the classroom. Teachers can quickly incorporate them into their teaching, to transform student learning and increase engagement. It means that in the constantly changing higher education system teachers and their pursued activities are exposed to new challenges and new demands.

A new educational paradigm in the higher education institution determines a multilevel teaching: contemporary teachers shall communicate new scientific knowledge and ideas by engaging members of the society into research; they shall pursue educational activity, be able to work in diverse educational environments and relate educational processes to daily activities. Teachers are encouraged to apply educational innovations: new methods, new work organisation forms, communication of the acquired knowledge, adoption and use of innovations (Sessoms, 2008). Therefore, besides current activities, innovative trends could be easily discerned in this process. Innovative work forms include the stages from the emergence of an idea to the final result, and close interaction between the organisation and its macroenvironment; usually this activity is analysed in the context of technological innovations (Luckin et al., 2012). In view of this, innovative activity is treated as generation of new ideas, innovation, modification, and the process creating new services/ methods etc. ICT, the use of smart educational products can help teachers bring more collaboration and interactivity into the classroom. Teachers can quickly incorporate them into their teaching, to transform student learning and increase engagement.

In the rare cases, the concept of innovative activity could be found in the context of social innovations. In this respect, the focus is given to the development, search for, adoption, implementation, dissemination, evaluation and communication of innovations. Thus, social innovations highlight the three core dimensions: satisfaction of human needs (content dimension), social relations, social inclusion (process dimension), and better opportunities for socio-political activity and access to resources (empowerment dimension) (Butkevičienè, 2009).

Innovative activity of teachers of the higher education institution is treated as a process specifically directed toward the establishment, adoption, implementation and application of educational innovations at different stakeholders' level aimed to improve the educational systems, and is related to various innovation implementation stages: innovation building and implementation of new technological processes (Bastic \& Leskovar-Spacapan, 2006). According to the researchers, the focus in the teachers' activity is given to the search for a new information, knowledge, methods and new measures. Thus, innovative activity is related to the innovative aspects contributing to the creation of new ideas. Over time this activity brings unique 
innovative achievements (Shavinina \& Seeratan, 2003), and this is a step forward toward innovations and willingness to change.

In conclusion, it could be said that the ambition of a contemporary higher education institution to pursue high level intellectual activity, create knowledge society and help students work and live in the knowledge society environment depends on the teachers' readiness to implement innovations in the pedagogical, scientific and dissemination activity.

\section{Methodology of the research}

The research was performed in the August - September of 2014. The respondents could use different ways of answers: they could provide answers by email or verbally during an interview. The account was taken of personal respondents' experience and their individuality providing a detailed and extensive picture of the situation. The focus was given not to the spread of the phenomenon, but to the understanding of specific cases providing for "movement" towards new research areas, better understanding of respondents' attitudes and life priorities (Bitinas, 2010).

Six teachers of University X (Faculty Y) were selected by applying a targeted random sampling. Since there were multiple informative population units, several options have been chosen and a smaller sample established. The data has been collected until a certain degree of theoretical "satiation" has been achieved. The research was aimed to evaluate teachers' readiness to integrate IT tools in the teaching/learning process and their experience in applying these tools for different purposes.

During the data collection period the scientific literature and documents regulating management, control and changes were analysed. The empiric data was collected by applying a semi-structured interview method. The research was based on the notion that respondents can use their concepts (words) instead of specific categories which are usually provided in advance. When selecting the research method it was decided (by anticipating the topics or problems to be discussed during interviews) not to get attached to the sequence of questions or anticipated words, and to freely change their order (Flick, 2009). Besides, the method of a semi-structured interview induced a more relaxed communication atmosphere, better adjustment to the research environment, and provided information contributing to an in-depth discussion of the problem under analysis. Selection of this method was determined by the possibility to get a detailed picture of the problem, identify causes of the phenomenon under analysis, and reveal subjective respondents' views and experiences.

The data obtained via a semi-structured interview was analysed by applying the method of a descriptive analysis (interpretation, contact identification) which included the following stages: multiple text readings and specification of categories via key words: division of category content into sub-categories, interpretation/substantiation 
of categories/sub-categories from the text evidence (Creswell, 2013). The analysis of teachers' skills and their readiness to apply ICTs in the study process was based on the humanistic personality theory. It served as the basis for the analysis of the teachers' role in the process of ICT implementation taking the strong view that every human and ng is a unique, organised and ever-changing personality aimed to create the future and realise own powers. In order to highlight a special nature of the above phenomenon and interpret it as a subject of conscientious individuals' experience, the reference was made to phenomenology. In the context of this research, phenomenological research design allowed to analyse personal respondents' experience and get acquainted with the teachers' evaluation of situation.

A quantitative expression of answers, i.e. the number of teachers attributed to one or another category or sub-category was not estimated. It was considered that opinion of each respondent is unique and valuable. The following ethical principles were applied during the research: voluntary approach, goodwill, privacy and respect. In order to ensure confidentiality of respondents, their names have been replaced with codes.

\section{Didactic factors of the application of educational technologies in the study process}

When analysing the data obtained during the study the main categories have been distinguished: the formulation of study objectives of a subject, the design of study content, application of methods and feedback.

The data obtained during the empirical study highlighted three key aspects of the formulation of study objectives of a subject: on the basis of program objectives; by combining with student personal objectives; by giving meaning to study objectives (Picture 1).

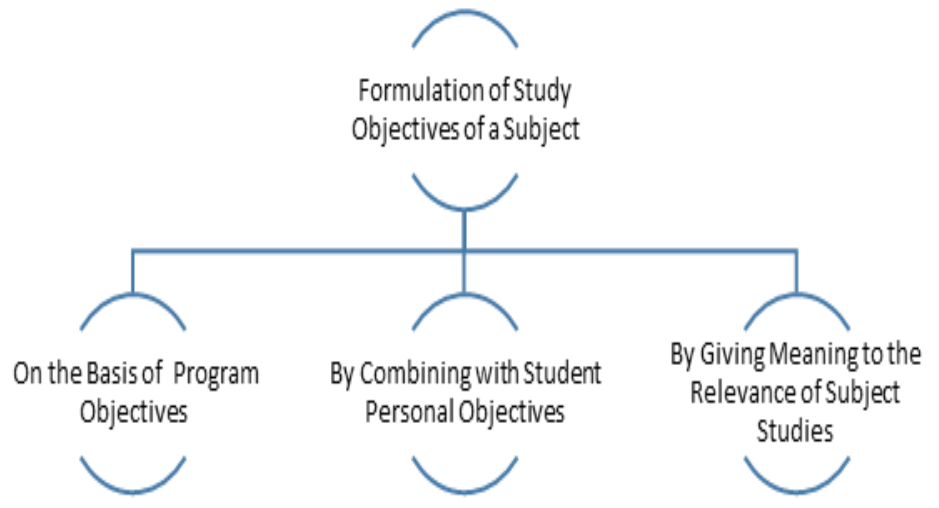

Picture 1. The formulation of the study objectives of a subject

The responses of the study participants enable to notice that when talking about teaching/learning objectives in the study process, the 1 teachers emphasise a formal structure when study and teaching/learning objectives have already been formulated, 
approved and presented in the description of a subject program. The informants maintain that they have to adhere to the objectives set out by the study programs, because "universitety studies is formal education and both the whole program itself and subjects they, anyway, are adopted and approved, therefore, you cannot change a lot, yes, you have adhere to that approved material" [E].

However, despite the fact that the study participants point out that the study objectives of a subject are always coordinated with learners while manoeuvring between formal objectives and students' needs and expectations: "So we go through those objectives, look at them and coordinate what additional ones would we need, which ones from those objectives we allow to remain. Well, we certainly always leave those basic, core objectives. $\langle\ldots>$ But, as much as it is possible, I try to respond to their expectations more $^{\prime \prime}[\mathrm{D}]$.

The discussion and formulation of the study objectives of a subject consists of two steps, usually during an introductory teacher or seminar: "First of all, they are briefed and the second question which is after the introduction when you have already briefed them, you ask, well, what they would like to hear additionally and the list of thoughts is compiled, isn't it, in the very beginning when their expectations are uttered" [A].

The experiences of the study participants relevantise the importance of students' needs and expectations in the study process when formulating the study objectives of a subject: "I take into account students' wishes, expectations, past experience" [B]; "it is very important to me that they would experience certain joy of learning" [E]. However, it is not concealed that "very often students themselves do not know what they want and it is very difficult to them to identify it" [D].

According to the study participants, it is particularly important that students would understand a study objective of a subject, therefore, an effort is made to explain why they study concrete knowledge: "I say all the time what I am after by doing that <...> and why it is relevant and how it can benefit them" [D], it is sought to assist in understanding the practical benefits, meaningfulness of subjects, competences: "you reveal importance, necessity " [E].

When generalising the responses presented in this category, it can be established that significant attention is paid to the formulation of objectives in the study process. The teachers adhere to the objectives set out in the description of a study subject, however, they always combine and adjust them, taking into consideration students' needs and interests. It is sought to reveal to students the necessity and importance of concrete knowledge, in order that the latter would understand study objectives and thus would experience teaching/learning success. It could be concluded that, by establishing conditions for students to set their own individual objectives, to act on the basis of their subjective expectations, the teachers rationally distribute responsibility for teaching/learning in the study process, encourage students to assume part of responsibility. 
Another distinguished category is the content design which encompasses two subcategories: aproved and unchanging and adjusted according to students' expectations (Picture 2).

When realising up-to-date educational technologies the content design is no less important factor than the formulation of objectives. In context of the educational paradigm shift, this process is based on the direct link between professional knowledge and the experiences of personal daily life.

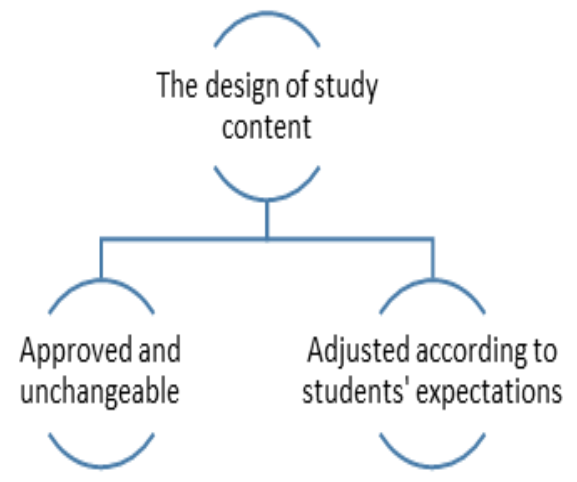

Picture 2. The design of the study content of a subject

During the study it turned out that the formation of the study content of a subject in the study process varies between oficial standards and learners' needs and expectations. Authentic responses of the informants reveal that the study content of a subject is officially approved and presented in the study system, therefore, it is subject to little change. However, the teachers constantly manoeuvre, combining the officially approved content with personal interests of students: "you have to adhere to that approved material, certainly that you perhaps coordinate with students" [E]; ,, here, in this case we manoeuvre with students <...> usually those things are always coordinated" [D].

The teachers adjust the material of their course, taking into consideration students' wishes, their interests: "students themselves utter what they want to study" $[\mathrm{C}]$. In addition, it is important to pay attention to the fact that when choosing the study content of a subject students' past experience is taken into account: "I take into account students' wishes, expectations, past experience" [B]. It shows the realisation of constructivist approaches in the study process: students, while forming their skills, new meanings and deepening knowledge, have an opportunity to use what they already know, to link their previous experience with new understanding. Thus as the data analysis shows, the teachers, taking into consideration students' expectations, complement their content or make it more concrete.

The data analysis of the study shows that study methods and their application is an important didactic factor (Picture 3). 


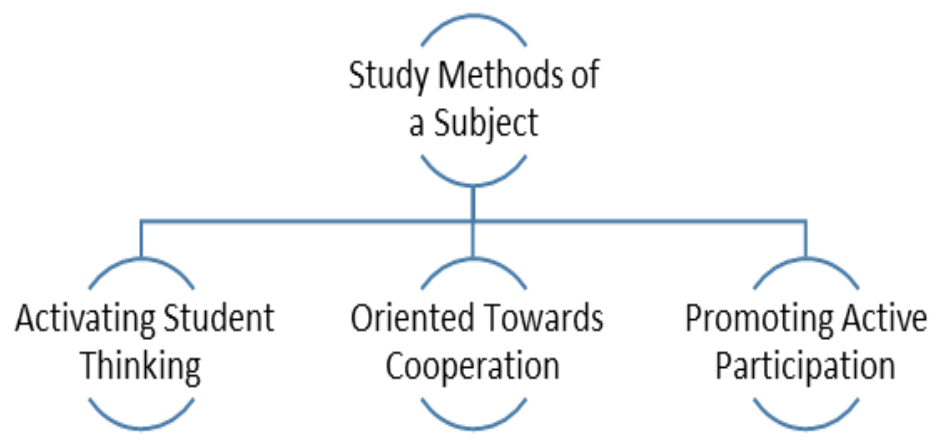

Picture 3. The application of study methods

When analysing the data of the study a subcategory was distinguished - methods which activate student thinking. The informants point out that while designing and implementing the process they have an objective to develop critical thinking in learners. It is sought by applying active teaching/learning methods as well: "to raise questions relevant to a student, set learning objectives and look for answers to them by applying brainstorming, vortex, open-ended sentences, 'I know - I want to know' and other methods of similar nature" [B], teamwork or discussions: "by comparing different, let's say, opinions, yes, which occurs in discussions $<\ldots>$ the performing of common tasks" [E].

In order to activate student thinking, the teachers apply methods related to the asking of questions: "open-ended questions, initiation, telling why that is important, why that question is important" [A] "and asking questions - answers to each other" [C] The results of the study show that, in the study process, the teachers apply cooperative teaching/learning methods. The informants note that, not in all the situations, and not all the students are inclined to cooperate with other learners: "not all express themselves, rush, are inclined to cooperate" [E]. It is maintained that students are not inclined to cooperate in different groups when, while performing a longer-term tasks, the groups, which have been formed before, are dissolved: "I have encountered the fact that they change unwillingly <...> You need to encourage that cooperation between groups a little" [A].

However, although, in the opinion of the study participants, the lack of communication and cooperation between students in the study process is not dominating, the teachers are inclined to encourage learners' communication and cooperation by giving "tasks to a pair of students or a little group of students" [B], by encouraging to actively work in more diverse groups as well: "It has really been recently, well, last year, this year that I have already started doing a little different thing <...> I try mixing them, I try changing by doing that through a team role test" [A].

The data obtained during the study show that the teachers encourage studentus to get engaged in an activity, to actively participate in the teaching/learning process. The study participants point out that they use interactive teaching/learning methods during 
all the academic sessions: "I introduce interactive teaching methods, such as: discussion questions, problematic questions" [A].

According to the informants, students engagement in active participation in the study process of a subject also depends on subjective factors, the factors that influence students: "it depends, in a great measure, on students themselves, on their motivation, whether students are motivated, whether they are not motivated, what they need and what they want" [D].

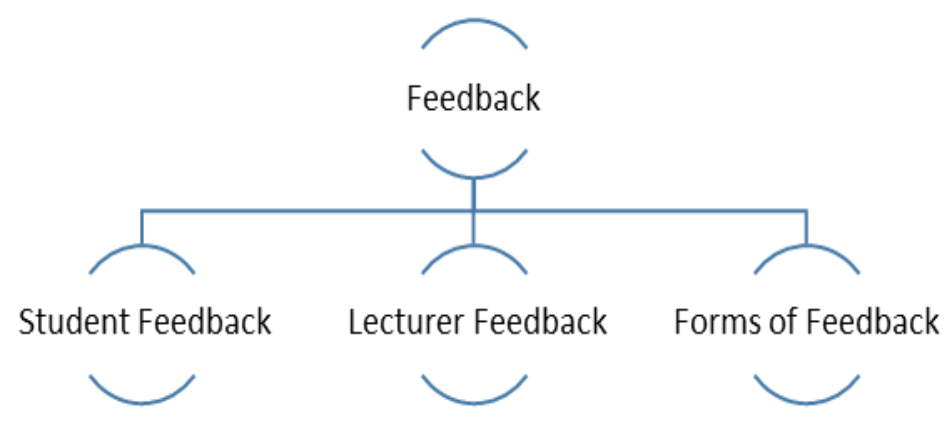

Picture 4. Feedback in the study process

When generalising the aspects highlighted in this category, it could be concluded that the study participants endeavour to create an active teaching/learning process, when organising the study process they apply different means to activise students, use active teaching/learning methods.

In the context of modern study process, the importance and necessity of feedback raise no doubts. The latter encourages both interested parties - teachers and students - to talk over teaching/learning, have a mutual discussion, assists in checking the successfulness of teaching/learning and a pedagogical activity. The expression of feedback in the study process creates conditions to work more purposefully and more effectively, in order that success would be achieved.

The data of the carried out study highlighted mutual interaction of the participants of the study process when reflecting teaching/learning (Picture 4). The distinguished "Feedback" category is explained by three subcategories: student feedback; teacher feedback; the forms offeedback.

When talking about the feedback provided by students, the study participants point out the expression of the latter through practical activity: when performing different tasks, answering the presented questions, applying active teaching/learning methods solution modelling, a case study. The experiences presented by the study participants relevantise the feedback provided by students as an ongoing, continuous process: "after each $l$ teacher, after each seminar" [A] and "during the evaluation of the course" [C]; "at the end of the course" [F]. The informants underline that feedback is realised while understanding its importance and benefit to the teaching/ learning 
process: "students themselves provide their feedback, so we here again talk then why it is good" [A].

The second subcategory highlights the expression of teachers feedback in the study process. The study established that the teachers provide feedback information both verbally and in writing. Students usually receive feedback information from a teachers either personally or collectively when, while discussing, the teaching/learning process is talked over: "I discuss with students once again what they received and what they, however, would lack" [D].

The study established that, in the study process, feedback is realised in different forms. Out of the authentic responses presented by the informants formal and informal feedback could be distinguished. Informal feedback is received when students respond to the study process, while constantly observing them or during discussions with them as well. The information from a teachers identify warm and friendly mutual relationships, cosy atmosphere as an important condition for the realisation of feedback: "that they would be able to freely express their opinion and that they would feel free" [D]. Whereas formal information about student achievements, their progress is received having assessed the works performed by students and when they receive a formal assessment - a mark.

Thus taking into consideration the fairly detailed opinions on feedback presented by the study participants, it would be possible to relevantise the importance of the latter to the study process by highlighting the fact that feedback is actively realised in different forms by all the participants of the teaching/learning processes.

\section{Conclusions}

In the study process, teaching/learning objectives are always discussed with students, the latter also have an opportunity to set their own individual study objectives, they are continuously kept informed why they study concrete knowledge and what it will be needed for in the future. When encouraging students to choose and pursue individual objectives, to act on the basis of their subjective expectations, the teachers create conditions to students to assume responsibility for their learning.

The creation of an environment favourable to studies is also proved by the fact that an opportunity is given to students to combine the study content of a subject with their own personal experience, interests. The teachers endeavour to motivate studentus, they constantly encourage them to communicate and cooperate, actively get engaged in an activity, thus empowering personal development of an individual.

The experiences of the teachers of the higher education institution and subjective opinions revealed that the study process is dominated by the study process of the active creation and construction of knowledge. The studies are oriented not only towards knowledge trasmission and its reception, particular attention is paid to active teaching/learning of students, their own engagement in an activity, active process of 
the construction of meanings and knowledge the core axis of which is a learner. When designing and carrying out the study process particular significance is attached by the teachers to the importance of feedback and its realisation in the study process, mutual relationships of an educator and learners. 


\section{REFERENCES}

AECT Standards, 2012 version. [interactive], [accessed 2015-09-12] $<$ http://c.ymcdn.com/sites/aect.siteym.com/resource/resmgr/AECT_Documents/AECT_Standards_adopted7_16_2.p $\mathrm{df}>$

Anderson, J. (2005) IT, e-learning and teacher development. International Education Journal. [interactive]. 5(5), 1-14. [accessed 2015-02-22] <http://files.eric.ed.gov/fulltext/EJ903883.pdf $>$.

Barnet, R., Coate, K. (2005). Engaging the Curriculum in Higher Education. Maidenhead: SRHE and Open University Press.

Bastic, M., Leskovar-Spacapan, G. 2006. What do transition organizations lack to be innovative. Kybernetes. 35(7/8), 36-45.

Bitinas, B. (2010) Gyvenimas ugdymo verpetuose. Klaipeda: Klaipėdos universiteto leidykla.

Brown, D., Warschauer, M. (2006). From the university to the elementary classroom: Students' experiences in learning to integrate technology in instruction. Journal of Technology and Teacher Education, 14(3), 599-621.

Butkevičienè, E. (2009) Social Innovations in Rural Communities: Methodological Framework and Empirical Evidence. Social Sciences. 1(63), 80-88.

Creswell J. W. (2013) Qualitative Inquiry and Research Design : Choosing Among Five Approaches. Los Angeles: SAGE Publications

Dromantienè, L., Indrašienè, V., Merfeldaitè, O., Prakapas, R. (2013) Teachers' professional development : the case of Lithuania. // A journal of research in education and training University of Ioannina publications. Ioannina : University of Ioannina, 6, 202-216.

Fredriksson, U., Gajek, E., Jedeskog, G. (2009) Ways to use ICTin schools to optimize the impact on teaching and learning. Acta Didactica Napocensia. 2 (4), 21-32.

Flick, U. (2009) An introduction to Qualitative Research. Fourth edition. SAGE Publications Ltd

Gao, P., Choy, D., Wong, A. F. L., \& Wu, J. (2009). Developing a better understanding of technology-based pedagogy. Australasian Journal of Educational Technology, 25(5), 714-730.

Greenhow, C., Robelia, B., \& Hughes, J. E. (2009). Learning, teaching, and scholarship in a digital age Web 2.0 and classroom research: What path should we take now? Educational Researcher, 38, 246-259.

Havelock, R., Hamilton, J. L. (2004) Guiding Change in Special Education. How to Help Schools With New Ideas and Practices. Corwin Press.

Hayashi, E. C. S., \& Baranauskas, M. C. C. (2013). Affectibility in Educational Technologies: A Socio-Technical Perspective for Design. Educational Technology \& Society, 16 (1), 57-68.

Ilomäki, L. (2008) The effects of ICT on school: teachers' and students' perspectives. Turun Yliopisto : Turku 
Indrašienė, V., Merfeldaitė, O., Railienè, A., Jegelevičienė, V. (2015) Experience in using information communication technology during lessons in general education schools. // The new educational review. Toruń : Wydawnictwo Adam Marszałek. 40(2 97-108.

Indrašienè, V., Sadauskas, J. (2013 The key attitudes towards organization of Bachelor's level studies. // EIIC 2013: proceedings in electronic international interdisciplinary conference, 2-6 September 2013 Žilina: EDIS - Publishing Institution of the University of Zilina.. 2, 551-556.

Youssef, B. A., Mounir, D. (2008) The Impact of ICT on Student Performance in Higher Education: Direct Effects, Indirect Effects and Organizational Change. The Economics of E-learning [interactive].5(1), 45-56 [accessed 2015-11-01]. < http://www.uoc.edu/rusc/5/1/dt/eng/benyoussef_dahmani.pdf >

Longworth, N. (2000).Making Lifelong Learning Work: Learning Cities for a Learning Century. London: Kogan Page.

Luckin, R., Blight, B., Manches, A., Ainsworth, Sh., Crook, Ch., Noss R.( 2012) Decoding Learning: The Proof, Promise and Potential of Digital Education. [interactive]. [accessed 2015-11-02]. http://www.nesta.org.uk/publications/decoding-learning

Luppicini, R. (2005). A Systems Definition of Educational Technology in Society. Educational Technology \& Society. [interactive]. 8 (3),103-109. [accessed 201511-02]. http://www.ifets.info/journals/8_3/10.pdf

Patankar, P., S., Jadhav, M., S (2013) Role of teachers' in curriculum development for teacher education [interactive]. [accessed 2015-10-17] $<$ http://www.researchgate.net/publication/258023165_ROLE_OF_TEACHERS_I N_CURRICULUM_DEVELOPMENT_FOR_TEACHER_EDUCATION>

Rastauskienè, G. J. and kt. (2008) Aš koncepcija: kognityviojo komponento raiška tarp Lietuvos aukštụjų mokyklų dèstytojų. Acta Paedagogica Vilnensia. 20(3),,12-31.

Ross, S. M (2010). Educational Technology Research Past and Present: Balancing Rigor and Relevance to Impact School Learning. Contemporary Educational Technology [interactive]. 1 (1), 17-35 [accessed 2015-10-17] < http://www.cedtech.net/articles/11/112.pdf>

Sessoms, D.(2008) Interactive instruction: Creating interactive learning environments through tomorrow's teachers. International Journal of Technology in Teaching and Learning, 4 (2), 86-96.

Shavinina, L. V., Seeratan K. L. (2003) On the nature of individual innovation. International Handbook on Innovation Oxford, UK: Elsevier Science. 31-43.

Spector, J.M., Merrill ,M.D. (2008) Special issue: Effective, efficient and engaging (E³) learning in a digital age. Distance Education. 29 (2), 123 -126.

Stoll L., Fink D. (1998) Keičiame mokyklą. Vilnius: Margi raštai.

Šiaučiukienė L., Čiužas R., Pedagogų didaktinès kompetencijos raiška Lietuvos mokyklose // Pedagogika. 2007, 86, 23-29

Zhu, Ch. (2010) Teacher roles and adoption of educational technology in the Chinese 
context. Journal for Educational Research Online. [interactive]. 2, 72-86 [accessed 2015-10-01] <http://www.pedocs.de/volltexte/2011/4576/pdf/JERO_2010_2_Zhu_Teacher_ro les_and_adoption_of_educational_S72_D_A.pdf $>$ 